Jpn. J. Oral Biol., $32:$ 317-322, 1990.

\title{
ORIGINAL
}

\section{Observations on striated muscle cells which appeared in rat infraorbital nerve after alcohol blocking}

\author{
Shigeo Aiyama, Tomoyo Imamura*, Seiji Takahashi*, \\ Hideki Furuya ${ }^{*}$, Rie Ikeda and Takanori Matsuoka \\ Department of Histology, Department of Anesthesiology*, School of \\ Dentistry at Tokyo, Nippon Dental University, \\ 1-9-20 Fujimi, Chiyodaku, Tokyo 120, Japan \\ [Accepted for publication: January 17, 1990]
}

Key words: Striated muscle cell/peripheral nerve/alcohol blocking/rat

\begin{abstract}
To study morphological changes in the nervous tissue blocked by alcohol, the infraorbital nerves of rats were blocked. One month after alcohol blocking, the occurring of striated muscle cells was confirmed in the rats' infraorbital nerves. These striated muscle cells looked like skeletal muscle cells. Our speculation is that the occurrence was due to the differentiation of the satellite cells or myoblasts that migrated to the blocked region. However, the possibility cannot totally be ruled out that other cells of neuroectodermal origin or fibroblasts in the infraorbital nerve differentiated into muscle cells under the stimulus of alcohol blocking.
\end{abstract}

\section{Introduction}

To study morphological changes in nervous tissue blocked by alcohol, the infraorbital nerves of rats were blocked. One month after alcohol blocking, muscle cells were found occurring in nerve fiber bundles of the infraorbital nerves. They bore some resem. blance to skeletal muscle cells in structure.

There are reports on the heterotopical development of striated muscle cells in the hypophysis $^{1,2)}$, lung ${ }^{3,4)}$, meninges ${ }^{5-10)}$, thymus ${ }^{11}$ and peripheral nerves ${ }^{12)}$. The occurrence of the striated muscle cell in peripheral nerves has been reported in the inferior laryngeal nerve ${ }^{12)}$.

In the present paper, the morphological features of the striated muscle cells that appeared in the infraorbital nerve of the rat after alcohol blocking are reported. At the same time, their origin is discussed.

\section{Materials and Methods}

About forty male Wistar rats weighing
300-400 g were used. As an anesthetic, 0.004 $-0.006 \mathrm{mg} / \mathrm{kg}$ of pentobarbital sodium was administrated intraperitoneally. After that, the skin and the facial muscle near the right infraorbital foramen were cut open with meticulous care in order to not damage blood vessels, and the infraorbital nerve was exposed.

For nerve blocking, $99.5 \%$ ethyl alcohol was used. By means of a $1 \mathrm{~m} l$ syringe for use in tuberculin tests, $0.1-0.2 \mathrm{ml}$ of ethyl alcohol was droped into the area surrounding the infraorbital nerve. The infraorbital nerve was left immersed for about 10 minutes in the alcohol, so that it could permeate between the nerve fibers. The infraorbital nerve was then put back where in had been, and the skin was sutured with metal needle clips. To prevent inflammation, $0.2 \mathrm{ml}$ of penicillin $G$ was injected into the muscle of the thigh.

To investigate morphological changes that might have been brought about by alcohol blocking, the infraorbital nerves were 
removed after the rats were again anesthetized by the same anesthetic agent. The extracted nerves were first fixed in $2.5 \%$ glutaraldehyde (0.5 M cacodylate buffer, $\mathrm{pH} 7.4)$ and then in $1 \%$ osmium tetraoxide. Dehydration was done by ethyl alcohol, and clearing with propylene oxide. Epoxy resin was used in embedding. The embedded nerves were sliced into $1 \mu \mathrm{m}$ sections, which were stained with toluidine blue, and examined under a light microscope. Ultra-thin sections were also prepared and stained with uranyl acetate and lead citrate for observation with an electron microscope.

\section{Results}

Striated muscle cells were found in two out of about forty rats used in this experi. ment. Two striated muscle cells were confirmed; One was contained in each of two nerve fiber bundles among nerve fiber bundles in the two rats' right infraorbital nerves. Probably due to the effect of the blocking, many of the nerve fiber bundles had disappeared. Around the two nerve fiber bundles containing striated muscle cells, there were scarcely any other bundles left. In their place, well-developed fibrous connective tissue was seen (Fig. 1). The blocking also seemed to have affected the nerve fibers. In both of the nerve fiber bundles containing a striated muscle cell, only a few myelinated

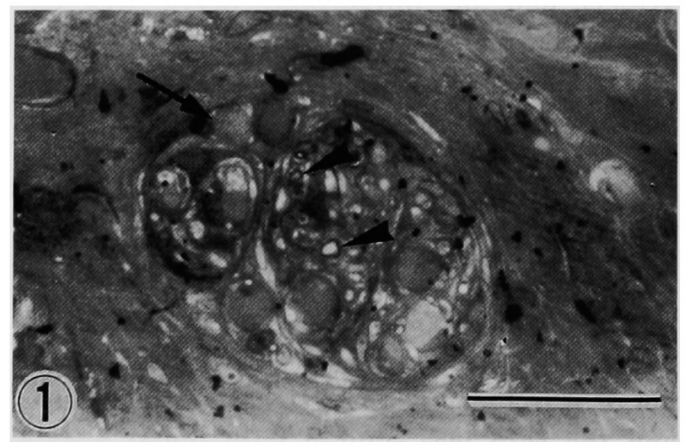

Fig. 1 Light micrograph of a degenerated nerve fiber bundle containing a striated muscle cell (arrow) and a few myelinated nerve fibers (arrow head). Well-developed fibrous connective tissue can be seen around the nerve fiber bundle. Bar $=50 \mu \mathrm{m}$ nerve fibers and non-myelinated nerve fibers were observed. Also in the bundle macrophage-like cells that engulf degenerated nerve fibers and cells of various shapes with processes and clear cytoplasm were found (Figs. 2 and 3 ). The two striated muscle cells recog. nized in our experiment were found near the perineurium of the nerve fiber bundles (Figs. 2, 3 and 4).

The muscle cell, as shown in Fig. 3, was enclosed by cells with long processes and clear cytoplasm.

The striated muscle cells were about 9.0 $\mu \mathrm{m}$ in length (Fig. 4), and about $7.2 \mu \mathrm{m}$ (Fig. 3) and $3.8 \mu \mathrm{m}$ (Fig. 4) in width.

The myofibrils varied in length and width, and ran almost parallel with the long axis of the muscle cell. The wider myofibrils contained a large number of myofilaments. In the areas between the myofibrils and around the myofibrils that face the plasma mem. brane, sarcoplasm was clustered. In the sarcoplasm mitochondria, sarcoplasmic reticulum, and many glycogen granules were found (Figs. 3 and 5). In the longitudinal section of the striated muscle cell triad-like structures were found (Fig. 5). Cross striations were formed in the myofibrils. Longer myofibrils had well-developed I band, A band, $\mathrm{H}$ band, $\mathrm{M}$ and $\mathrm{Z}$ lines. Adjacent myofibrils had also a similar arrangement of bands and lines (Fig. 5).

A basement membrane, part of which was not clearly visible, seemed to surround the striated muscle cell.

The nucleus was not clearly seen in the sections of the two muscle cells, indicating that these cells have only one or two nuclei.

There was no neuro-muscular junction in evidence.

\section{Discussion}

We unexpectedly found striated muscle cells in the nerve fiber bundles of the rats' infraorbital nerve blocked by alcohol. There are several reports on the heterotopical occurrence of striated muscle cells in the hypophysis $^{1,2)}$, thymus ${ }^{11)}$, and peripheral nerves ${ }^{12}$, and the lung ${ }^{3,4)}$ and meninges ${ }^{5-10)}$ which had developmental anomalies. In these studies, striated muscle cells were found occurring 


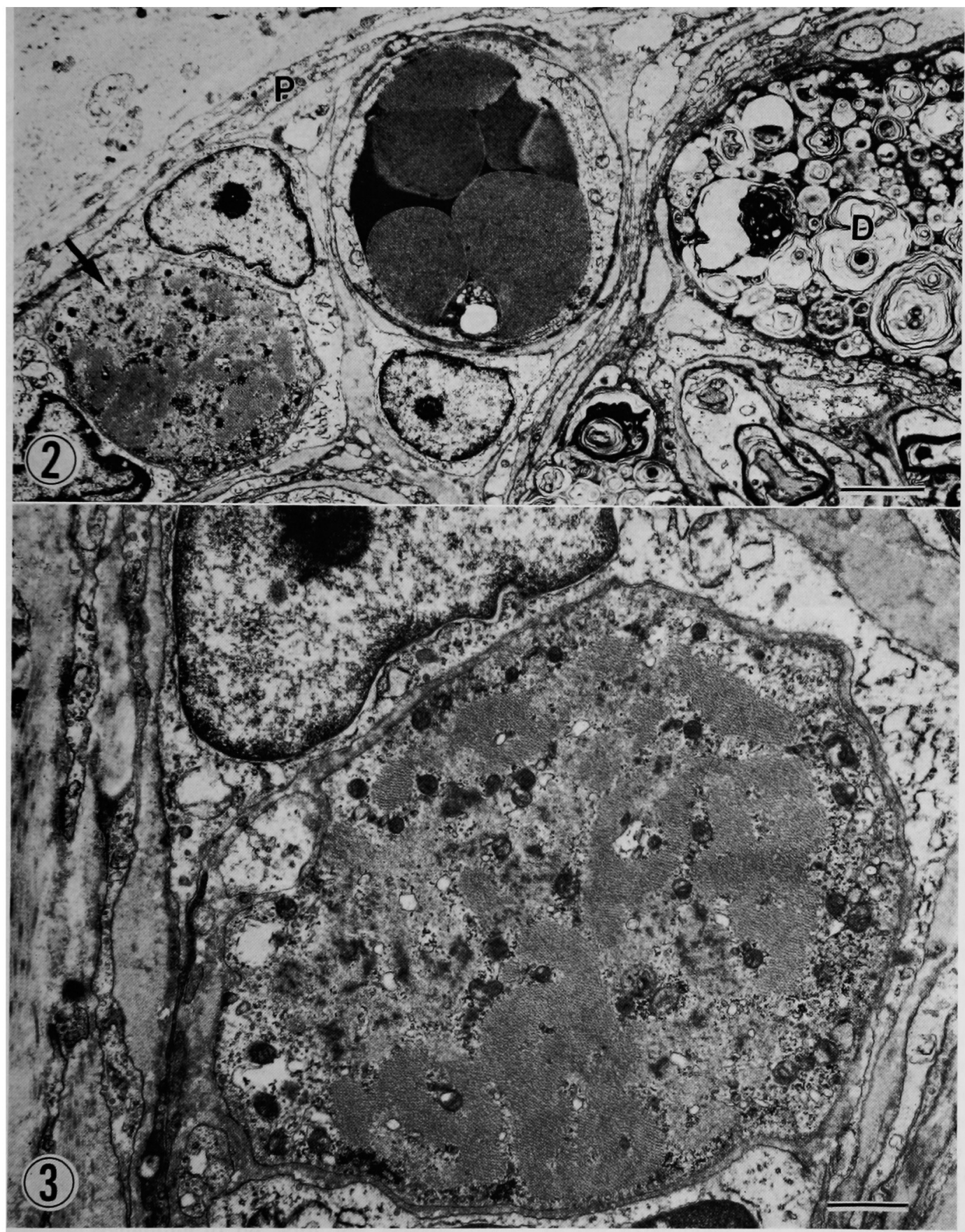

Fig. 2 Electron micrograph of a part of the degenerated nerve fiber bundle containing a striated muscle cell (arrow). D : degenerated nerve fiber $\mathrm{P}$ : perineurium $\mathrm{Bar}=3 \mu \mathrm{m}$

Fig. 3 Higher magnification of the striated muscle cell shown in Fig. 2. The muscle cell is enclosed by a cell with long processes and clear cytoplasm. The various sizes of the myofibrils are seen within the sarcoplasm. Bar $=1 \mu \mathrm{m}$ 


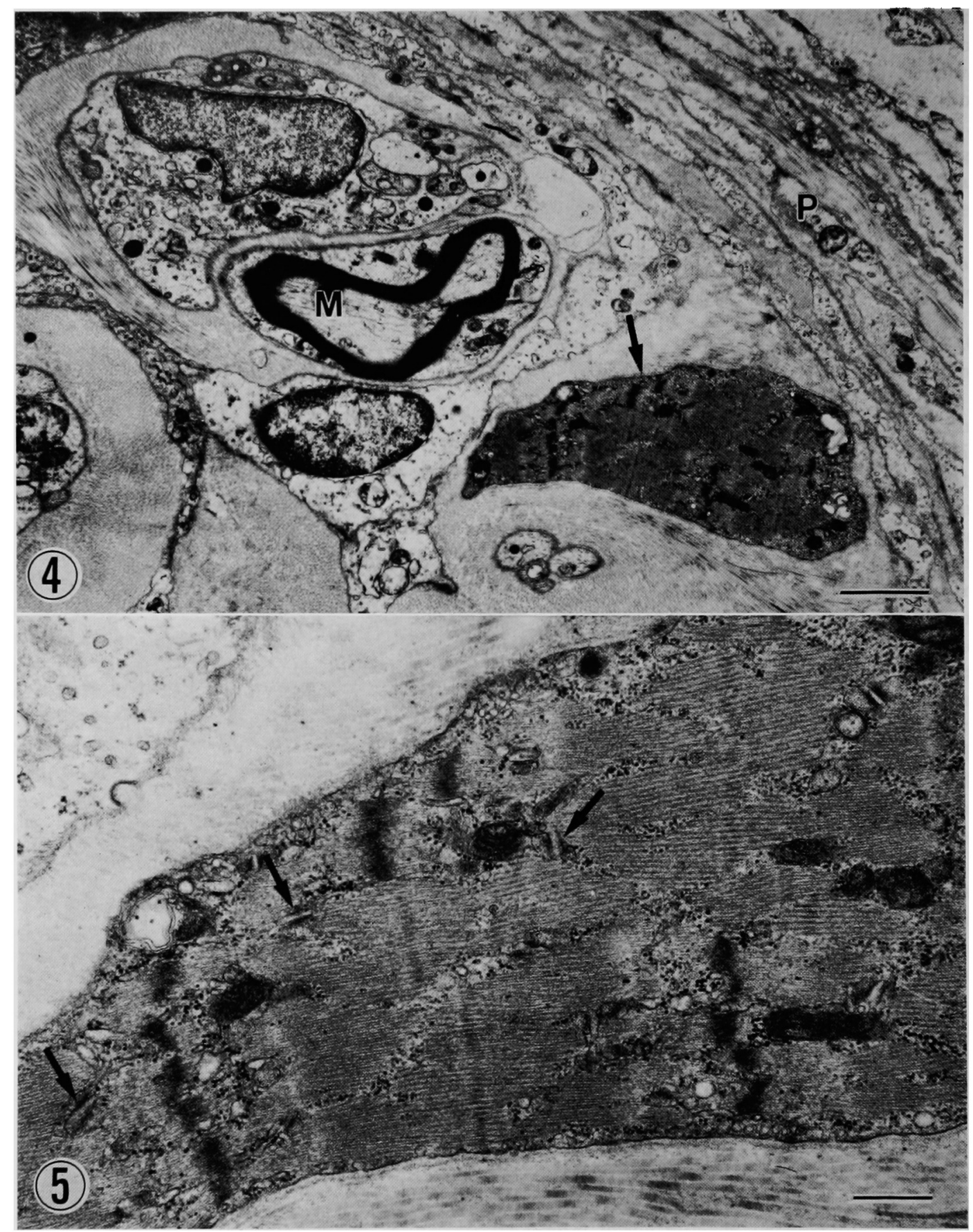

Fig. 4 Electron micrograph of a part of the degenerated nerve fiber bundle containing a striated muscle cell (arrow) seen in an infraorbital nerve other than that in Fig. 2. M : myelinated nerve fiber, $\mathrm{P}$ : perineurium. $\mathrm{Bar}=2 \mu \mathrm{m}$

Fig. 5 Higher magnification of the striated muscle cell shown in Fig. 4. The cross striations are formed along the length of the myofibrils. The triad-like structures (arrow) are seen in several parts of the myofibrils. Bar $=0.5 \mu \mathrm{m}$ 
singly or in a bundle of four to five at the most. In our study we found two striated muscle cells, one in each of the two infraorbital nerves. The fact that striated umscle cells do not occur in large numbers seems to give researchers a very limited chance of discovering them.

The striated muscle cells detected in the hypophysis $^{1,2)}$, lung ${ }^{3,4)}$, meninges ${ }^{5-10)}$, thymus $^{11}$ and inferior laryngeal nerve ${ }^{12)}$ were reportedly very much like skeletal muscle cells. In our case, the two striated muscle cells were very small and no nuclei were seen in the sections. Moreover, there are points yet to be clarified concerning fusion between cells. Despite all this, the two striated muscle cells could be compared with the skeletal muscle cells on the grounds that 1) A band, $\mathrm{I}$ band, $\mathrm{H}$ band, $\mathrm{M}$ line and $\mathrm{Z}$ line are welldeveloped; 2) a triad-like structure is seen near the boundary between $\mathrm{A}$ and I bands; and 3) there is no desmosome.

Regarding the origin of the striated muscle cells that developed heterotopically, various hypotheses are proposed. One is that the striated muscle cells occurring in the leptomeninges covering man's brain originate in the neuroectoderm ${ }^{10}$, but according to others from the prechordal mesoderm ${ }^{7)}$. Some researchers argue that the cells heterotopically formed in the leptomeninges of the rat cerebellum derive from the neuroectoderm ${ }^{5}$.

Others maintain that the cells in the leptomeninges covering the spinal cord in the mouse and rabbit have their origin in the somatic mesoderm ${ }^{9-10}$ ). Moreover, it is reported that mouse fibroblasts can be converted into myogenic cells by 5 -azacytidine treated cultures ${ }^{13}$.

In our case, it is out of the bounds of the possibility that the prechordal mesoderm took part, since no developmental anomaly was observed either in the face or the head of the rat. The possibility that the somatic mesoderm had something to do with the heterotopical occurrence can be ruled out in view of the position of the infraorbital nerve.

Because the facial muscles exist in the outer layer of the infraorbital nerve, it can be presumed that, after alcohol blocking, the satellite cells coexisting in the facial muscles migrated to the infraorbital nerve. It is known that the satellite cells tend to differentiate into myoblasts and, when transplanted into an injured part, differentiate into striated muscle cells $^{14,15)}$. There are reports ${ }^{16)}$ that the satellite cells of the host tissue sometimes move to the grafts and are transformed into striated muscle cells.

Furthermore, some researchers hold the view that the myoblasts travel in the bloodstream ${ }^{17}$. Considering this and other views, it is possible to say that in our experiment, the myoblasts were carried into the area blocked by alcohol and changed into the striated muscle cells.

The hypothesis that striated muscle cells originate in the neuroectoderm is congruous with the view that the striated muscle cells occur as a result of the differentiation of the neural crest. Lennon et al. ${ }^{18)}$ cultured neuroectoderm-derived glial cells and confirmed the presence of striated muscle cells. It is known that, in the head and neck regions, neural crest cells differentiate into ganglia and Schwann cells besides meninges and glial cells ${ }^{19)}$.

The emergence of striated muscle cells in the peripheral nervous system was reported by $\operatorname{Voss}^{12)}$ in 1964 . He detected striated muscle cells in the inferior laryngeal nerve free from artificial interruption. The striated muscle cells indicated by Voss were, therefore, considered to have occurred congenitally.

His study also seems to suggest the possibility that the striated muscle cells of neuroectodermal origin could occur in the peripheral nerves in the head and neck region.

The report ${ }^{13}$ that myogenic cells were expressed in cultures of mouse fibroblasts treated with 5-azacytidine may alo be agreeable to the results of our experiment, because it is possible that fibroblasts in the infraorbital nerve can be converted into myogenic cells by the stimulus of alcohol blocking.

In our experiment, the facial muscles and infraorbital nerve tissues, in which striated muscle cells were detected, were physiologically manipulated beforehand. Therefore, there is a strong likelihood that either satellite cells or myoblasts got into the infraorbital nerve tissues somehow and differen- 
tiated into striated muscle cells. However, the possibility cannot totally be ruled out that some types of neuroectoderm-derived cells or fibroblasts in the infraorbital nerve differentiated into striated muscle cells under the stimulus of alcohol blocking.

\section{Acknowledgment}

We thank Ms. Sumie Kobayashi, Department of Histology, School of Dentistry at Tokyo, Nippon Dental University for her technical assistance.

抄録：アルコールブロックによって生ずる眼窩下神経の組織構造の変化を調べる目的で，ラットを用いて 夷験を行ってきた。その結果, ブロック後 1 カ月目の眼窩下神経のブロック部位の神経束内に横紋筋細胞が 認められた。横紋筋細胞は骨格筋細胞に似ていた。ブロック部位に現れた横紋笳細胞の由来は, この部位に 移動してきた筋衛星細胞または筋来細胞が横紋筋細胞に分化した可能性がもっとも高いと思われる。しかし， 神経堤由来の細胞や線維芽細胞の横紋筋細胞への分化が報告されているので，神経束に含まれる神経堤由来 の細胞または線維芽細胞がアルコールブロックに刺激された結果, 筋細胞に分化した可能性も示唆される。

\section{References}

1) Brunner, G. and Tschank, G. : Contracting striated muscle fibers differentiated from primary rat pituitary cultures. Cell Tissue Res. $224: 655-662,1982$.

2) Inoue, K., Taniguchi, Y. and Kurosumi, K. : Differentiation of striated muscle fibers in pituitary gland grafts transplanted beneath the kidney capsule. Arch. histol. Jpn. 50 : $567-578,1987$.

3) Aterman, K. and Patel, S. : Striated muscle in lung. Am. J. Anat. 128: 341-358, 1970.

4) Drut, R. M., Quijano, G., Drut, R. and Heras, J. L. : Rhabdomyomatous dysplasia of the lung. Pediatr. Pathol. $8: 385-390$, 1988.

5) Ohanian, C.: The occurrence of striated muscle within the cerebellum of the albino rat. Acta Anat. 71 : 108-111, 1968.

6) Hoffman, S. F. and Rorke, L. B. : On finding striated muscle in the brain. J. Neurol. Neurosurg. Psychiat. 34:761-764, 1971.

7) Ambler, M. W.: Striated muscle cells in the leptomeninges in cerebral dysplasia. Acta Neuropath. 40 : 269-271, 1977.

8) Lipow, K., Horoupian, D. S. and Raine, C. $\mathrm{S}$.: On the occurrence of striated muscle within the spinal leptomeninges. Muscle Nerve $1: 322-329,1978$.

9) Raine, C. S. and Horoupian, D. S. : Skeletal muscle within the spinal leptomeninges of the mouse. Muscle Nerve 3:187, 1980.

10) Nakamura, Y., Nakashima, T., Komatsu, Y., Hashimoto, T. and Hachisuka, H. : Striated muscle cells in the leptomeninges. An immunohistochemical study. Arch.
Pathol. Lab. Med. 108 : 561-563, 1984.

11) Wekerle, H., Paterson, B., Ketelsen, U..P. and Feldman, M.: Striated muscle fibers differentiate in monolayer cultures of adult thymus reticulum. Nature 256: 493-494, 1975.

12) Voss, H.: Ein histologisches Kuriosum : Quergestreifte Muskelfasern in einem Nerven. Anat. Anz. 115 : 469-472, 1964.

13) Taylor, S. M. and Jones, P. A.: Multiple new phenotypes induced in $10 \mathrm{~T} 1 / 2$ and $3 \mathrm{~T} 3$ cells treated with 5-azacytidine. Cell 17 : 771-779, 1979.

14) Snow, M. K.: An autoradiographic study of satellite cell diffrentiation into regenerating myotubes following transplantation of muscles in young rats. Cell Tissue Res. 186: 535-540, 1978.

15) Lipton, B. H. and Schultz, E. : Developmental fate of skeletal muscle satellite cells. Science 205 : 1292-1294, 1979.

16) Grounds, M. D. and Pantridge, T. A. : Isoenzyme studies of whole muscle grafts and movement of muscle precusor cells. Cell Tissue Res. 230 : 677-688, 1983.

17) Bateson, B. G., Woodrow, D. F. and Slopen, J. C. : Circulating cell as a source of myo. blast in regenerating injured mammalian skeletal muscle. Nature 213: 1035-1036, 1967.

18) Lennon, V. A., Peterson, S. and Schubert, D. : Neuroectoderm markers retained in phenotypical skeletal muscle cells arising from a glial cell line. Nature 281 : 586-588, 1979.

19) Moore, K. L.: The developing human. Clinically oriented embryology. 3rd edn., pp. 74-76, W. B. Saunders company, Philadelphia, 1982. 